\title{
Forståaleg språk for alle
}

\section{Rapport frå ein nordisk konferanse om klarspråk}

Kongsberg, 4. - 6. november 2004

REDIGERT AV JAN OLAV FRETLAND OG MARIT HOVDENAK

Det er viktig å rette fokus på å ligge

$i$ forkant $i$ forbold til

den pågående utviklingen...! 